\title{
Networks of desire
}

The Specter of AIDS and the Use of Digital Media in the Quest for Secret Same-Sex Relations in São Paulo

\section{Richard Miskolci}

\section{Abstract}

This article seeks to analyze the emergence of an on-line market for love and sex partners in São Paulo, as of 1997, when the internet became commercially available in Brazil. Focusing on the first generation of digital media users, my field research looks at men who entered adolescence or adulthood during the AIDS epidemic. I analyze how the use of digital media has been molded by people's desire to dissociate themselves from the image that homosexuality acquired during the sex panic. In Brazil's largest metropolis, this use of digital media is linked to historical and cultural transformations within the realm of homosexualities, as they move under the aegis of an erotic regime based on the desire for social adjustment.

Keywords: digital media, sex market, male homosexualities, AIDS, subjective and corporeal transformations. 


\section{Networks of desire}

The Specter of AIDS and the Use of Digital Media in the Quest for Secret Same-Sex Relations in São Paulo'

\section{Richard Miskolci}

Diogo ${ }^{3}$, a thirty five year old liberal professional from São Paulo city, cannot remember exactly when he got on the internet for the first time, but from the very start, he used this new resource to arrange dates with other men: "It was completely new, it was at the end of 1990s, I was finishing my undergraduate degree and was only going out with women, but I was really curious about going out with a guy... secretly. I got on chat and also on an on-line dating site. I still have a profile on those sites. And for the last two years I also use Grindr."

Diogo lives in an upper middle class neighborhood and works in the financial market. He claims to lead "a predominantly straight life", but has incorporated the use of new digital media into his daily life to such an extent that he reports he "lives on line," using sites and applications to find sexual partners and sustain a social network which he considers he would not have access to if it were not for these technologies. As is the case for most of those who collaborated with me on this research project, he expressed the enormous pleasure he takes in this form of socializing.

Since 2007, I have been doing ethnographic research on men who use digital media in search of other men for love or sex in the city of São Paulo. ${ }^{4}$ My contact with them began through participant observation in chat rooms for gay and bi-sexual men living there, and I went on to do extensive interviewing - written and through video-conference - with the thirteen who consented to it. I also met five of them in person, four of whom I have been able to stay in touch with, following through on their lives for a period of more than three years. One is more recent. They are all at least thirty years of age today,

\footnotetext{
1 Special thanks to Richard Parker and Peter Fry for their insightful comments on this paper.

2 Department of Sociology - UFSCar

3 I have changed all names used here, in order to preserve the anonymity of those who participated in my ethnography.

4 The research is sponsored by CNPq (The National Council for Scientific and Technological Development, Brazil, www.cnpq.br) and follows its ethical requirements.
} 
have university degrees, work as liberal professionals (lawyer, business manager, doctor, economist and musician), are white and upper middle class, and come from Catholic families from smaller cities in São Paulo or neighboring states, but have been living in São Paulo's capital city for many years.

They have all been using digital media since 1997, in other words, since the Internet was made available commercially in Brazil, and since that time have made use of it to find partners for sex and love. Thus, the use of digital media that I analyze in this article is marked by generational affiliation, yet not one which would lend support to the notion of beginners' "lack of skill" in dealing with these technological instruments. On the contrary, the people in my research make up part of a generation that is privileged insofar as it was the first to learn how to put these medias to use and how to do it well. At present, according to the Internet Management Committee, close to 80 million Brazilians have access to the web (almost $42 \%$ of the country's population) and in São Paulo, its largest metropolitan area, more than two thirds of its 20 million inhabitants have web access. ${ }^{5}$ At the time my collaborators ${ }^{6}$ were beginning their use of the internet, however, it had quite a different social profile. Its users were, in their overwhelming majority, people from the upper and upper middle classes.

This contemporary Brazilian reality is part of recent social and historical processes in the sphere of sexuality, associated with major changes that began in the decade of the 196os. This is when, as Jeffrey Weeks has pointed out, the process of liberalization, secularization and growing "individualization" of sexuality begins. He enumerates four major recent transformations in the sphere of sexuality and eroticism:

The first is the democratization and informalization of personal relations that sees the gradual development of profound caesuras: between sex and reproduction, between sexual relations and marriage, between marriage and parenting. Second, we see the development of a highly conscious sense of sexual agency, especially on the part of women and increasingly lesbians and gay men (...) Third, I suggest is a profoundly important reshaping of the boundaries between public and private (...) Finally, a heightened sense of "risk" is dramatized

5 The Brazilian Internet Steering Committee website is available in English on http://www.cgi.br| english/index.htm. IBOPE Nielsen Online has also released data about the internet access in Brazil: http:\| www.ibope.com.br/pt-br/Paginas/home.aspx

6 I have decided to refer to the participants in my ethnography as "collaborators", as a way of emphasizing the help they have given me in its development. 
by the HIV/AIDS crisis from the early 1980s. (Weeks 2007: XI-XII)

The above-mentioned changes are interrelated and, within the sphere of homosexualities, are associated with economic, socio-demographic and political change. And it is in the context of post World War II economic growth and the passage to post-Fordism that the consumer society marked by greater room for leisure and the cultivation of life styles emerges. Since the decade of the 1960 , consumption and eroticism increasingly mold our lives, modifying our subjectivities, identities and social relations (Crane 2006; Gregori 2010; Preciado 2008).

With regard to the way these transformations intersect with technologies, Nancy Baym (2010) has argued that, the contemporary use of digital media is the most recent chapter in a long history of the desacralization of personal relations, that is, the erasure of boundaries separating the public and the private which began, most probably, with the popularization of the use of the telephone in the second half of the twentieth century. In what was initially a parallel process, personal computers came on the scene during the 1980 . These technological inventions were widely disseminated and moved closer to one another in the following decade. The linking of telephones and personal computers made commercial internet use possible in the decade of the 1990 .

In Brazil, this historical turn in modes of communication took place somewhat later, but also more radically. Unlike the pattern prevailing in "central" countries, in which the home telephone became common as of the 1950s, residential telephones in Brazil remained expensive and therefore were commonly found only in the homes of the relatively wealthy upper classes until the $198 \mathrm{os}$. The privatization of telecommunications midway through the 1990 inaugurated a drastic increase in access to phone lines, giving a boost to commercial internet services, most markedly as of 1997.

Nineteen ninety seven is also a crucial year for understanding this new scenario within the context of Brazilian homosexualities, a year marked by several significant events: in addition to the emergence of commercial internet, it was also when the free distribution of drugs for HIV treatment began and the first year that what became the world-prominent São Paulo Gay Pride Parade took place. These facts are thus associated with an historical turn taken in the way Brazilian society understands the universe of homosexualities.

The internet made possible the creation of relational networks that would have be unthinkable for previous generations. These networks now connect 
people who once lived their desires predominantly in a secret or solitary way. Furthermore, AIDS drug treatments began little by little to diminish the sexual panic that had sprung up around the epidemic and, at the same time, gave rise to a new way of seeing AIDS - no longer as a fatal illness but as one that was susceptible to treatment. This has led to the contemporary perspective according to which the disease can be seen primarily as chronic, although it is a view that health authorities attempt to contest (Pelúcio and Miskolci 2009). Gay Pride Parades and columns in newspapers and journals associated with the expansion of commerce directed to a homosexual public have also helped to foster this new visibility.

Middle and upper class adult men who grew up during the Brazilian military dictatorship (1964-1985) were affected by overwhelmingly negative images of homosexuality. Their teen years were marked by the impact of the AIDS-related sexual panic. They experienced the post-1997 shift as adults, thus constituting a veritable transition generation situated between those who had lived most of their lives without access to technologies, medicines and more positive forms of political and media visibility and those who were born and raised within this new scenario. Fernando Seffner's research (2003) on a bisexual men's postal network, between 1995 and 2000, provides an excellent overview of the previous generation, marked primarily by negative images of same sex relations. In his view, these negative images were intensified by the way media presented the AIDS epidemic. Thus, the men with same sex desires who took part in his research attempted to avoid association with homosexuals (2003: 112), preferring to advance the possibility of a bisexual identity.

Seffner's work bears some similarities to my research, yet there are also some significant differences. Among the similarities is his focus on men that have sex with men, but do not aspire to a gay identity; in terms of findings, his interlocutors also valued secrecy (2003: 240). Among the differences, I would highlight the fact Seffner analyzed a generation born around 10 years before the one I explore, his larger sample (around 5oo people, 306 engaged in long exchange of letters) and the fact that he built his connection to them through a non-profit mailing network based on the exchange of letters. In contrast, my research deals with a new generation, my sample is smaller and more socially homogenous and the persons I work with do not consider the possibility of a bisexual identity. It is also important to consider that I made 
contact with my interlocutors through the internet and that mobile networks increase the role of the "market" in their lives, in comparison with the non-profit exchange of letters Seffner analyzed.

In contrast to the generation studied by Seffner and the younger ones, Diogo is a member of the generation that I have denominated as transitional. While previous generations were obliged to deal with stigmas about same sex desire, associated with "perversion", mental or psychological disorders, or religious notions of sin, Diogo's cohort grew to adulthood at a time in which male to male relations began to be seen as an epidemiological problem characterized by the risk of infection. His memories of the epidemic, and also about internet use, go back to the end of the 199os, but also help to understand the uses that he gives, even today, to applications for mobile devices like tablets and cell phones.

\section{Desires, markets and digital media}

According to Eva Illouz (2006), the on-line search for partners is part of the history of the relationship between love and capitalism. In her book Consuming the Romantic Utopia (1997), Illouz asserts that after the First World War, new desires were bred within the commercial and media context of mass society. In the West, and particularly in the United States of America, traditions of separate socialization of young men and women and courting within the parental household yielded to a new practice of dating: the romantic encounter in which boy takes girl out for a "date" outside the family abode.

The substitution of the old patterns of romantic courtship under strict familial control with the individualized encounter in a public environment is related to changes in values and in the position of men and women in social life, but also to the invention of the automobile, the popularization of the movies and the growth of an entertainment industry. Advertising and film began to work as key forces molding people's desires and ideals (Illouz 1997: 33). Thus it becomes important to draw attention to an aspect that has been frequently neglected in studies on love and sexuality: how desires and feelings are both created by and feed into the creation of technology.

If film and publicity have been so fundamental to the invention of "dating" over a large portion of Western society, the former have also encouraged the use of the automobile not only for utilitarian purposes but also and above 
all, as a place for intimacy and even sexual experimentation. This observation is corroborated by the strong emphasis that advertising has given, throughout the decades, to linking cars to masculinity and sexual conquest. In the case of erotic contacts between men, it was not long before certain movie theaters and certain parking lots in big cities or outside them became meeting places for men seeking sexual contact with other men.

Something similar began to occur with the advent of the revolution in information technologies. Manuel Castells explored this deep social transformation in his works from the 1980s, which he then went on to summarize in The Rise of Network Society (1996). More recent works like Scott McQuire's The Media City: media, architecture and urban space (2008) associate the digital media turn to new means of producing social space and new forms of social agency. In Anthropology, Tom Boellstorff's book Coming of Age in Second Life (2008) shows how an ethnographic approach can improve and expand the achievements made by digital media scholars who have placed priority on issues of economic and public sphere impact. ${ }^{7}$

From a perspective that is also attentive to the impact that these technologies have on private and sexual life and love, digital media can be seen as enabling the creation of selective relational networks within a sex and love market. Relationships emerging through the use of digital media become part of an interwoven dynamics of desire and market interests that make up what I understand as "networks of desire": people's desire for partners in love and sex - or even for friendship - undergirds their use.

The men who have collaborated in my ethnography, even those who have female partners or who are currently involved with a man, continue to use chats, websites and applications in search of partners. This then demonstrates that there is no univocal relationship between being without a partner and looking for one online - the search itself should be seen a source of pleasure. It attracts people, among other reasons, because of the possibility that Illouz has noted: it makes potential partners visible. In other words, the media beckon us by removing the blinds around a form of relationship market.

7 Boellstorff explores how friendship plays a major role in online relations (2008: 157). Despite his statement that sexual relationships were not the core of his interlocutor's lives within the social platform he examined, he also adds: "I encountered many cases of bisexual men and women who were heterosexually married, had chosen to be monogamous with their opposite-gender spouse in the actual world, but with their spouse's blessing pursued same-gender sex and even relationships in Second Life.” (2008: 165) 
In the case of the men in my research, there is a differential component, insofar as they are seeking other men through platforms and applications that provide them with the anonymity they covet, enabling them to express their desires with relative safety and to enjoy prohibited pleasure in their daily lives: flirting with other men.

The desire guiding the quest, therefore, cannot be reduced to sexual desire. This is corroborated by the fact that neither momentary satisfaction of sexual desire, nor fulfillment within a relational context, necessarily lead users to distance themselves from digital media. In addition to this particularity in the use of digital media by men who seek amorous or sexual liaison with other men, there is also a market logic that seems increasingly to impose itself through the perception that relationships are time-bound and that there are always other options available, perhaps better ones. In Illouz' view: "No technology I know of has radicalized in such an extreme way the notion of the self as a 'chooser' and the idea that the romantic encounter should be the result of the best possible choice. That is, the virtual encounter is literally organized within the structure of the market (2006: 7)."

The premise that it is possible to make romantic choices through the market is reinforced by the most popular mechanism that dating sites offer: the personal interview or questionnaire. In sites geared toward the formation of "stable" relationships, such as the Brazilian version of Match.com, which goes by the name Par Perfeito [Perfect Match], questionnaires have been created in conformance with an ideology of compatibility (Beleli 2012). According to Illouz, one of the most famous, e-harmony, was created by a clinical psychologist who hoped to identify possibilities for successful marriage (2006: 4). These questionnaires/search engines offer an ample number of "choices" for particular questions that have been formulated, regarding personal tests, professional profile and the type of partner the respondent is seeking. To a certain extent, the search engine works as an instrument for giving concrete or visible form to the user's desire.

In sites geared toward men who are seeking relations with other men, there is a clear sexualization of search mechanisms, with an emphasis on bodily characteristics such as age, height, weight, build, sexual position, eye color, hair, body hairiness, penis size and erotic interests. (Zago 2009; 2013). This gives us an idea why such sites are so profitable - they promote a visualization of what is available in the sex/romance market and apparently offer 
the means for "making the best choice". Above all, they place the user within a new economy of sex and romance that is no longer marked by the scarcity of dates and potential partners "off line" but rather by the presumed abundance of opportunities and people available on line.

Sites that are used for finding "stable" couple relations are almost all "heterosexual", although there is a non-negligible presence of women who seek relations with other women and, to a lesser extent, men who seek men (Beleli 2012: 68). In turn, the chat rooms and sites that are geared toward an all-male population are heavily sexualized. In Brazil, until quite recently, chat rooms and searches set up with a homosexual or bi-sexual population in mind were always situated in the "Sex" department of those sites. It was not until 2012 that the UOL (Universo Online) chat room service, the most popular in São Paulo, created the first set of rooms for same sex romance.

The most popular [non-straight] dating sites in Brazil are Manhunt.com and Disponivel.com ["available".com]; their very names imply that their purpose is to facilitate "hunting for a man" or taking advantage of what is "available on the market". There is also significant evidence that dating sites, as a business sphere, tend to associate heterosexuality with a quest for love [romance] and homosexuality with a quest for sex; heterosexuality, it would seem, is associated with some degree of non-market psycho-social compatibility, relegating (male) homosexualities to a market guided by a search/hunt that associates desire and interest.

In spite of the above-mentioned separation, it is not hard to find users who affirm that they use online platforms with goals that are quite distinct from those imagined or proposed by those who have set them up or run them. There are women who use sites meant for romance and couple-forming to find sex, just as there are men who seek some sort of stable relationship through sites set up for casual encounters. Furthermore, as observation and follow up on the life of my collaborators in the city of São Paulo shows, encounters that begin merely with sex in mind may turn into something that is more lasting (Miskolci 2013).

Use of an on-line dating site or application for cell phone or tablet begins with creating a user profile. This always demands a certain amount of reflection on the self. One must choose a name or nickname, a headline and present a description of oneself which, in Illouz' terms, involves a process of "textualization of subjectivity" (2006: 6) and analyzed recently by the Argentine 
researcher and Brazilian resident, Paula Sibilia, in her book O Show do Eu (2008) [The Me Show]. This process also leads to the creation of profiles that have been referred to as false or fake, yet studies like Vessela Misheva's (2011) indicate that most people, through their profiles, want to create an "authentic image" of themselves.

The search for authenticity represents a challenge, especially when we are guided by our own self-image, which we are also creating for the reception and evaluation of others. It is the other who will judge the adequacy or the inconsistency or imprecision between profile and user. That is, an "outside" perspective is just as marked by its own subjectivity as that of the person who created the profile. Thus, both of the people involved become enmeshed in the uncertain logic of contemporary fascination with the notion of authenticity (Turkle 2011: 183).

People are also motivated to add at least one profile photo, an aspect that brings the body into the picture, quite literally. Choice of photos is marked by and thus reveals the user's cultural references, but reflects, above all, a process of "commodification" of the self, an attempt to present oneself as "saleable" on the sex/romance market. In a number of ways that are not necessarily made explicit, the user is encouraged to represent himself or herself as a personality of publicity, film and fashion - and to use his/her photo as a "shop window of the self".

Part of the charm of using these sites comes from the very process that turns people from media spectators to what could be seen as a type of participant/protagonist. If choice of photos leads to a consciousness of the centrality of physical appearance within the love/sex market, it becomes all the more exacerbated as the person proceeds in filling out the simplest of questionnaires, for which numbers are given or options are checked off: age, height, weight, etc. In sites set up to help men find other men, this is the type of data that tends to be given the most importance. This is evidence of the significance the body takes on between men, established as the principal form of personal capital within this highly competitive arena.

Contrary to early analysis of the internet which saw it as a "disembodied" sphere of social activity - probably due to the limited resources that were available therein during the decade of the 199os - the online world has revealed itself more and more "embodying". When the internet began, written language was predominant. Yet it moved quickly toward other forms of visual 
expression. This is demonstrated in my collaborators' accounts on how, toward the end of the 199os, they bought scanners, enabling them to digitalize photos for exchange with other users via e-mail, or for posting on dating sites. Not long thereafter, webcams became available, but were infrequently used due to their price and problems with the speed and quality of connections. At the beginning of the decade of 2000, photos taken in digital cameras started to be posted on photo blogs. No surprise, then, that these cameras soon became a common possession, and photo blog links were passed on to others through Messenger and chat rooms. In more recent years videos, cameras and microphones have become basic elements in whose absence contacts are limited.

To a certain extent, the old "date" has become instant and no longer requires physical presence in public space, now substituted through the use of a Messenger or other video-conference programs. This new form of connection is more individualized, anonymous and intimate. It is not rare for users to use a portable computer from their own bedroom or even from bed. Thus, they may present themselves to a potential partner from an already intimate angle, suggesting and often ending up with exposure of nude bodies that both parties involved in the interaction may evaluate.

In my fieldwork, the frequent reports I heard of video interaction that ended in blocking the other person after he showed his body or face seem to indicate at least two distinctions that can be made between these contacts and those that are made off-line. Online, people deal with their contacts in a somewhat depersonalized way. Above all, the evaluation of another person follows more rigid patterns and demands higher and harder to meet bodily standards than in off-line scenarios. Thus, rather than constituting a "disembodying" medium, digital media reveal themselves as highly-focused on corporeality as the key to contact. ${ }^{8}$

In online contacts between men, there is veritable dispute over who evaluates and who is the evaluator. Competition is contextual and, in the case of my collaborators, mostly men who have commitments to women, they assume that it is the other person - particularly if this person is single "who should exhibit himself more". Thus, they expose the body, but reserve their faces as the "reward" for a personal encounter. They are usually men who

8 On this aspect see Mowlabocus analysis of cybercarnality "'From the web comes a man: profiles, identity and embodiment in gay dating/sex websites" in Mowlabocus 2010: 147-182. 
show skill in transforming invisibility into an attribute for potential partners who are seeking a discreet person "out of the scene": someone who initially refuses to reveal his face on-line, thereby inciting the other's imagination with the possibility of meeting heterosexual men who only sporadically seek homosexual contacts.

Most of the men whom I accompanied in their use of these sites applied a pre-conceived model of what they were looking for, such that however wide the universe of potential partners on the website data base, a refined search tends to limit them to a small pool of "interesting" profiles. When they get in touch with the people that they have identified in this manner, the number of replies they get back is even smaller. Notwithstanding the varying degrees of frustration that this scenario produces, men go on searching rather than leave the site. They continue negotiating the terms of their search, since idealized [exact] criteria tend to prove unrealistic.

In contrast to what sites boast and clients desire, the use of search mechanisms guarantees neither dates nor relationships. This is due in the first place to the fact that people tend to seek persons who are "better" than they are, that is, partners who are more socially recognized as "good-looking", also associated with aspects such as youth and place of residence. As data, the neighborhood in which a person lives is more than mere geographic location - rather, it denotes social class, income and life style.

Thus, in São Paulo, the neighborhood called Jardins [Gardens] and surrounding areas are highly valued. The Eastern Zone of the city is devalued, considered poor and working class -despite the fact that it also includes some upper middle class areas such as Tatuapé and Jardim Anália Franco. A closer look at what is going on enables us to see the centrality that is placed on the neighborhoods of Jardins, Higienópolis and Vila Nova Conceição and the contempt for the Eastern Zone of the city as forms of evaluating consumption circuits and life styles in which the latter part of the city has come to be considered, in on line terms, the "Lost Zone". Elite neighborhoods are, on the other hand, seen as the center where a life of privileged access to consumption and social recognition unfold.

As I have already stated, the desire that underlies the search is one of social adequacy as much as sexual desire. In São Paulo, one of the most frequently repeated online questions is, "What are you looking for?". The most common answers tend to be evasive and uncertain. Some people seem not 
have the faintest idea of what they want, while most summarize similar lack of definition with the oft-repeated, "whatever happens", meant more as a manifestation of being open to the other's intentions than a real willingness to accept anything. The goal of the search is uncertain or highly idealized in the image of a "dream person", yet high value is placed on the search in and of itself, as I was able to verify through the persistent investment that my collaborators make in it.

Some of my collaborators reported that they have kept profiles in a number of dating sites and applications for over a decade already, and use the comments of other users who define themselves as "eternally on line" to show that this is a common situation. Among them, my collaborators mention two profiles that are among the most common on the sites Manhunt and Disponivel.com: men who seem to correspond to or at least come close to the type of profile they are looking for, yet whose continued online presence over the course of the years raises the issue of their apparent inability to find what they are looking for. ${ }^{9}$

The first is the profile of a 28 year-old man who currently presents himself under the headline "Hot Hung Brazilian Guy" - "Dotado Sarado". He describes himself as "macho, well-endowed, 1.93 m, $103 \mathrm{~kg}$, muscular 12\%", in which the latter percentage is a reference to his low rate of body fat. In the photos he has posted - almost all of which show him bare-chested on the beach - as well as in his more detailed description, it is apparent that he is trying to present himself in a very standardized way that fits the model of the upper middle class gay male and supposed participant in international consumption circuits. "Dotado Sarado" defines himself as a dominant top guy, provides information on the size of his penis and observes that he does not like to penetrate other men.

The second profile to which my collaborators have made much reference belongs to a 39 year old men, who presents himself in the following way: "I AM a MATURE, GOOD TEMPERED STUD...WANNA TRY?” He is a tall (1.84 $\mathrm{m})$ white man who is well built, hairy-chested and whose description begins "I AM NOT an internet 'whore', even though I am here". He defines himself as top and claims to be looking for a relationship in which he can be a "real

9 Despite the fact profiles are public and open to anyone that creates an account on the website, for ethical reasons I do not reproduce them neither offer their user names. 
good husband".

The profile of the 28 year old is more sexualized and does not make necessary reference to the desire for a relationship, while that of the 39 year old mixes appeals for sex and affection with the search for a romantic partner. What they both share is a strong emphasis on their own masculinity, as well as a desire for partners who are similarly masculine. They emphasize their active role in intimacy and, among their preferences, list "hetero/bi". It is not difficult to recognize these profiles and all that distinguishes them: they share an interest in placing themselves at a distance from the negative stereotypes of homosexuality that prevail in Brazilian society, associating it with "effeminateness" and "marginality".

Everything seems to indicate that their self-representation as men who, although seeking male sexual partners, are in complete conformity with socially recognized and desired notions of the masculine constitutes their greatest appeal. Furthermore, fitting the model so well yet maintaining this "perennial" presence on the net diminishes their credibility. It rouses not only curiosity but - above and beyond all - suspicions regarding their authenticity: what could be lurking behind their extremely stylized self-presentation?

Among the negative comments I heard at different moments during my research in relation to these profiles, two suspicions stood out: that of a "promiscuous gay" and of a "man who's got problems" respectively. In the first case, life style and body type are associated with reprehensible sexual behavior; in the second case, in which a romanticized profile presents the person as morally unobjectionable, the suspicion is that this is a person who is incapable of relating off-line. Yet in spite of the criticisms and suspicions that my collaborators voiced, in both profiles we can recognize an attractiveness that is attained through some sort of successful attempt at "purification". Dotado Sarado underscores the claim that he is not a drug user and the other man begins his self-presentation by asserting that he is not an "internet whore [puto]".

It is not within the scope of this study to speculate on the veracity of posted profiles - that is, the extent to which self-presentation and "reality" actually correspond. Rather, I explore the ideals and fears that guide the way profiles are created and "read" by my collaborators. Notwithstanding their ironic treatment of the quantity of users who claim to live in wealthy neighborhoods, it is precisely the men who reside therein that seem to be the 
object of their attention. "Effeteness", drug use and promiscuity stand out among their greatest fears, an injunction that is imposed in a manner that is both curious and efficient.

Promiscuity tends to be associated with a passive position in sexual relations, while predatory sexual behavior, associated with an active position, is seen as a virile attribute. A man who has a preference for being penetrated tends to be devalued on this market or will at least have a harder time than others in proving his virility and moral rectitude. This phenomenon helps us to understand the existence of so many profiles of men who claim to be top and looking for others who also are, or, as in "Dotado Sarado's" profile, refer to themselves as top men who do not like penetration. The devaluing of passivity also becomes visible through the absence of profiles of bottom men seeking similarly bottom partners. The "top" position is related to a highly valued masculine position that is associated, although without evidence, to men who also relate sexually to women. It may be this which has generated a considerable increase in recent times in nicknames and profiles in which users describe themselves not only as top but also as "straight" - even while they search for other men for sex and love through sites geared toward a homosexual public.

The profiles that my collaborators mention most frequently refer to men who present themselves as discreet, "out of the scene", "masculine", top or in variations such as "active/liberal", "flex" and the less frequently used "versatile". The devalued types are, on the other hand, not recalled in detail. "Rejected" profiles fall into the common junk pile of those who deserve contempt because they "live on the outskirts" of town or seem "effeminate", which in effect means that they are recognizably gay - judgments that become even more radical when a person declares himself as bottom.

\section{"Out of the scene" but online : the specter of AIDS lurking in the present}

Within this highly competitive market, the most valued commodity is the image of complete social adjustment, that is, someone who bears no outward signs of homosexuality. The need to distance oneself and possible contacts from the "gay scene" is evident, corroborated by the expression. "I'm out of the scene" that is repeated in many introductions and profiles. This phrase, 
according to someone interviewed by Isadora Lins França, comes from the decade of the 1980s, the period in which AIDS-related deaths reached their apex: "If you were a gay out of the gay scene - the expression 'out of the scene' [fora do meio] dates back to that time - , if you didn't hang out in those environments, you were less at risk (França 2010: 50).”

To be "out of the scene" and/or be looking for someone out of the scene was almost imperative during the time in which AIDS was considered fatal and being HIV-positive was equivalent to a death sentence. Internet use began when AIDS was still seen as a fatal disease and HIV positivity, as a highly disqualifying condition. In the words of one man who discovered he was HIV positive: "To die of AIDS at that time was a horrible, shameful thing. I don't know if you can imagine (...) The worst thing that could happen to a person was to contract AIDS. The worst! Worse than being a murderer. The ugliest, most disgusting (Zamboni 2012: 12).”

The specter of AIDS was projected onto bodies, as Grant Tyler Peterson and Eric Anderson observed for the U.S. case: “Men's suspicions of other men's serostatus functioned as a form of sexual survival and fostered an environment of systematic corporeal policing among men (2012: 126-127).” Within this context, the use of steroids, originally used to treat AIDS patients, was soon associated with practices of working out at the gym, geared toward body-building. Thus it was at the peak of AIDS-related deaths that this beauty standard emerged, associating health, masculinity, muscularity and, increasingly, lack of body hair. The success of male body hair removal is related to the demand for bodies that evoke strength and youth, meant to produce a contrast between them and those of the generation that had been devastated by the tragic consequences of the epidemic.

Commercial internet emerged, in Brazil, at more or less the same time that the anti-retroviral cocktail was invented, but much before the consolidation of the perception of the disease as "chronic". The use of the expression, "out of the scene", at least for the generation that we are looking at here, gives credibility to the hypothesis that for São Paulo men who seek relationships with other men, the use of digital media expanded and was even propelled by the AIDS-spurred sexual panic. A consequence of this is the growing - and now consolidated - association that my collaborators made between being discreet and having a well-muscled body, sarado (healed one in Portuguese). The expression sarado sprang up at the height of the AIDS epidemic to refer 
to muscular guys.

Although my collaborators rarely make overt reference to AIDS, its influence on the way they understand their desire for other men materializes indirectly in the specter evoked by the disqualifying use of the term "gay scene". When they assert they are "out of the scene" and are looking for someone who also is, they express an anxiety to dissociate themselves from environments or behaviors associated with the sexual promiscuity of the time in which AIDS related deaths were at their peak. At the beginning of the 1990s, that is, during the sexual panic, they were teens or young adults who quite likely associated the desire for other men to the risk of getting or dying from AIDS.

The AIDS panic not only created subjectivities in search of purification, but a new male corporeality which was linked to a "health and fitness generation" [geração saúde in Portuguese]. In André Masseno's words:

This health and fitness generation, with its way of thinking, introjecting and educating the body (..) did not cease to represent a response to the AIDS virus epidemic, which at that time was dizzily spreading over the land. The images that the media exhibited of men with muscular bodies, healthy complexion and playing sports on and around beaches sought to establish a public counterpoint to the proliferation of sunken, wasted faces of people who were infected, increasingly present within the social arena of the time (2011: 2219).

Thus, at the end of the twentieth century, commercial circuits where luxury and social recognition were sought substituted the older spaces for homosexual social life in major Brazilian cities. The internet emerged from this process and is intrinsically related to it, thus substituting an older "scene" for a segmented commercial circuit. It represents the possibility of individualized sexual access, free a culture or identity that had been equated with illness and the risk of death.

Among my collaborators - and this is particularly the case for the youngest ones - there is no longer a direct association between homosexuality and marginal experience associated with dangerous or socially stigmatized places such as saunas and red light districts. Nonetheless, the dominant view that posits any exclusively gay place as "impure" and as a point of contact with other forms of social marginality is still strong; in particular, the powerful myth that was socially constructed over decades associating homosexuality with deviation from social and familial values persists. 
In the face of this ghost from the past, particularly alive in the minds of men who are over thirty, new digital media have emerged as privileged means that allow people to establish individualized, anonymous and above all, "clean" forms of contact. In fact, these media sell the idea that they work as mechanisms that enable people to select whom they contact. Never before did the market seem to enjoy such affinity with hegemonic morality as it does in these sites and applications that are able to sell the possibility of choosing, thanks to users' subjective willingness to associate the search for dates and partners with a form of purification.

In the face of the supposed immorality or superficiality of meeting points and social spaces linked to promiscuity, these platforms offer their clients the comforting idea that it is possible to socialize without exposing oneself, in a controlled and selective way. Although they permit "transgression" of the heterosexism and homophobia that permeate most of daily life, the use of digital media indicate something similar to what Larissa Pelúcio et al. found in their analysis of betrayal sites ${ }^{10}$ : "transgression that favors the [social] order" (2012).

Although in fact I tend to agree with Eva Illouz regarding the existence of a sex and love market, my ethnographic work shows that its economy cannot be reduced to a logic of accounting and rationality. Holding strictly to the hypothesis of the interdependence between capitalism and the sex market would inhibit us from looking at elements of this economy that go beyond mere cost-benefit analysis. There are also other values that define our search for love and sex. Even though internet dating sites and applications for mobile devices are part of a commercial circuit, they are seen as instruments to access this circuit without exposing oneself and without a complete acceptance of all of its values.

In the face of moral "condemnation" of the "scene" as a space of immorality and promiscuity, the lucrative business of sites and applications offers a supposedly clean space that allows for selection. Search mechanisms act as filters which permit the subject who uses them to gain access to a morally respectable sphere where true and false, pure and impure can be distinguished. Thus, they are effective in providing users with the sensation of being "out of the scene" and appear to offer the possibility to chose someone whom "even though he isn't perfect" is still "cleaner", "truer" or "more honest" than

10 Larissa Pelúcio (2012) has researched these websites that are geared toward an audience of married men and women who search for extra-conjugal lovers. They are very popular in Brazil, especially Ashley Madison or AM as people call it. 
someone who one might meet randomly.

For a large portion of my collaborators, a "family" morality seems to inhere even in the search for a partner for casual sex. A discourse of responsibility, family values and trust is what seems to most attract potential partners. I confirmed this through my own observations several years ago: the way in which men presented themselves on line as "Machos" or "Brothers" in constituting relations with other men, many of whom are openly homosexual (Miskolci 2013). The "familial" discourse of men who carry on relations with other men in secret "purifies" them, creating the apparent paradox in which their experience of secret homosexuality then appears not as weak character or evidence of "deceiving" their wives and families but as a commitment to socially prioritized values regarding family and wife or girlfriend. In this manner, they get involved in relations between "closeted" men or even others who are not necessarily in the closet in an apparent moral paradox: they tend to create contacts which, for the most part, are doomed to fall apart, interrupted sooner or later by the commitment to the partner with whom they are bound through heterosexual sociability.

It is the desire for social adequacy that marks my collaborators' online search for a partner. This explains why they indicate a preference for guys who live in rich neighborhoods, look "straight" and bear signs of hegemonic social position. I am aware of the polysemic meaning of the term "hegemonic", so it is important to specify that it refers here to the reality of upper and middle class São Paulo men, roughly between the ages of 30 and 45 years. For these men, it is the hegemonic which becomes erotic. This leads us to rethink what is meant by the "erotic regime". Rather than as a given or natural system connecting individuals on the basis of private or intimate interests, I suggest that we think of erotic regimes as historical, culturally-varied and grounded, as well (or perhaps predominantly) in collective interests.

Erotic regimes thereby become more important than most social theories have recognized. At the same time, they must not be thought of as a tabula rasa from which autonomous subjects seek to constitute relations - in fact, the point of view on which the study of supposedly minority sexualities was based. ${ }^{3}$ In this regard, and from the vantage point of what are still initial and exploratory reflections, my ethnographic fieldwork with university-educated men, white and of Catholic origin enables me to recognize a set of 
hierarchical classifications that are schematically sketched out in the tables below:

\section{Online Erotic Regime}

Middle and Upper class São Paulo men, white, between ages 30-45

\section{Physical Appearance}

Femininity

Masculinity

(self-labeled as gay)

(Discreet)

(passes as straight )

Older

Young

Passive/Bottom

Versatile

Active/Top

Fat Normal build Thin In shape Muscled/Athletic

\section{Socio-economic Origin}

Working Class Neighborhood

Middle Class

Elite

Underpaid Jobs Traditional Professions Management positions

Poverty Financial Dependence

Financial Independence

Jr/Sr. High school

College

Cultural Capital

North/NE origin Local/Southeast Europe/USA/South/Argentina

\section{Behavior/Values}

Multiple Partner

Monogamy / Sexual Predator

Moral Iconoclasts

"Family Values"

Drugs

Smoker

Drinker

"healthy"/fit

The diagrams above that I have tentatively named as "Appearance", "Socioeconomic origin" and "Behavior/values" are meant to have validity only in relation to current São Paulo realities and considered in relational, dynamic terms. The columns on the extreme right constitute the "ideal" that was most frequently mobilized by my research collaborators in their search for sex/love partners, in São Paulo, between 2007 and 2012. The middle column is indicative of how people negotiate between the above-mentioned ideal and what they actually find, and the left column attempts to condense those characteristics that are most frequently rejected, or even avoided, by my 
informants in their on line search for dates or partners.

As a whole and taken in a dynamic and situated manner, these diagrams permit a preliminary approximation to what I call erotic regime or network of desire, which in turn should be clearly distinguished from conceptions that are rooted in common sense or in some psychological theories. These conceptions and their premises naturalize the erotic sphere, associating it to desires which are understood as only or predominantly originating within individuals; perhaps we may think of them as remaining hostage to theories and sexual categories that do not enable us to capture the historical and located character of these social relations. In this case, the centrality of the image of complete social adjustment is evident, and in particular in a very concrete sense, which I will discuss in the following section: the ability to pass as straight.

\section{Network of Desire}

The desire that drives my collaborators in their use of new digital media is the desire to develop a social life in which eroticism oriented toward someone of the same sex can be expressed as normal. Many of them reported living in families or exercising professions that they qualify as conservative; they even see themselves as men with "traditional values". They also commonly describe the ways in which their desire for other men creates tensions - in diverse ways and forms - in their relationships with their colleagues, bosses or parents. In this context, social medias allow them to establish a comfort zone within daily life, whether at home or within the work environment, which then becomes more bearable.

Online, these men live a contemporary form of 'being adrift' that runs parallel to what Néstor Perlongher $(2008 ; 1987)$ described in his analysis of homosexual flirting in the decade of the 1980 os on the streets of São Paulo. The men he observed took pleasure in moving between heterosexual norms and homosexual margins, much like those in this study do through the use of digital media. This is something they experience without ever overcoming their fear of losing the privileges of their supposed heterosexuality. Thus, this "being adrift" is both a source of pleasure and of tension, creating a context in which desire and paranoia alternate and merge, never able to separate completely. In contrast to the men in Perlongher's field, my collaborators 
search for safe relations online and fear the environment and behavior of those searching for commercial sex in the streets. So, their "paranoia" is an unpleasant and undesired component of their online search.

Authors such as Sherry Turkle (2011) and Manuel Castells (2011) argue that we live in an era that is obsessed with being connected, that is we want to be online all the time, connected to others through cell phones, tablets and computers. In my fieldwork, the search for connection unfolds around the fact that daily life impedes or creates particular difficulties for experiencing desire and eroticism. This in turn leads to major psychic investment in one's own sexuality, pleasures and - "apparently" - in running the risk that sexual desires and practices oriented toward other men be "discovered" or have a negative impact on family, professional or love life (for example, if the man has a commitment to a woman).

The need to be discreet or secretive in one's relationships with other men underlies the uses that these men give to digital media, so that the desire for continuous connection and connectivity depends on the user's sensation of total control. If our social lives unfold through participation in these networks, what being online offers is the apparent possibility to create - "individually" - a network sociability that is completely adjusted to our interests. My collaborators search for and choose people with whom they establish sexual and emotional ties as well as friendships within an imperative of controlled segmentation of intimate life, insofar as their relations with other men are concerned. In other words, they seek to create a time/space of their own for a sphere of homosexual eroticism while at the same time, leaving the arena of family and work untouched "as much as possible".

Iara Beleli argues that the internet appears as a "network of information in which data are configured in such a way as to create in the user the illusion of control" (2012: 58). This illusion of control seems to be one of the major attractions of these media, a way of constructing segmented networks of relations, offering safety in contacts with people who come to learn each others' secret. Adding to this illusion of control and safety is the fact that the use of platforms and applications becomes a "rational" form of search, counterbalancing the powerful stereotype that same sex desires belong to the domain of the irrational and uncontrollable. At the same time, some reflection on a sensation that some of my collaborators report seeking on line - and that they refer to as "adrenaline" - is worth further consideration. It mixes the desire 
for the prohibited and its fulfillment, reinforcing an image that is deeply rooted in Brazilian culture, that men should live their desire without ever losing self-control (Villela 1998, Seffner 2003: 211).

Within this online context, sociability is constructed through the imagined position of a relatively autonomous, liberal individual. Thus, it is no coincidence that users participate in a sphere of "weak ties" that is highly coveted by people who in their daily lives, have no one with whom to share their sexual interests nor wish to expose their desire to family members or colleagues. Weak ties seem safer, for, in the end, these are the ones that link them to persons with whom they do not develop deep and lasting commitments, as they would with friends, family members and partners. These "ties" aid them in the constitution of networks shaped through a logic of shared interests, where "friends" are those with whom they share a common interest or activity, falling within what Wellman (1998) has referred to as a culture of network individualism, an individualized version of community.

New medias provide degrees of control, the possibility of choice, the safety of anonymity but mainly with the promise that, through them, the user is able to create a personal, alternative or parallel version of society or of the social circles in which s/he normally participates. Residing within these desires or intentions is an erasure of the boundaries between public and private that is similar to that which has created an altered sense of privacy in people; this, in Turkle's view, can be gleaned in the way in which people use the cell phone in public, assuming that "those around them will treat them not only as anonymous but as if absent" (2011: 55).

Understanding current usage of digital media requires an analysis of new ways of articulating public and private life, by modifying or even inverting our way of getting to know one another: it now begins within our own personal, intimate space and only later leads to face-to-face encounter. As Beleli observes: "This subversion enables us to reveal desires that we would not be inclined to make known in a first face-to-face encounter (2012: 68)." In other words, intimate and even erotic desires act as defining elements in our relations with others as of the first moments of contact.

In my fieldwork, many informants reported that digital medias facilitated sporadic sexual encounters which were followed by a loss of contact with the person. They classified encounters that generate greater contact as less frequent and rare those that lead to the development of a "friendship" or 
relationship. They attributed this to a variety of factors, amongst which we find a certain disqualification of the other in virtue of his availability. This is similar to what Eva Illouz has noted in heterosexual contexts. Thus, within the online sex and love market, seen as an infinite source of novelty and abundant options, when a face-to-face encounter finally occurs, the person often seems less interesting that $\mathrm{s} / \mathrm{he}$ did online, representing an unfulfilled possibility, a desire rather than a consummated fact. Moreover, within my fieldwork, off line contact may often "disqualify" the other by virtue of his own sexual availability, sometimes confounded with signs of "promiscuity".

This regime of visibility is supported by heterosexuality, which is also the erotic regime in which most of my collaborators participate, maintaining relationships with female partners. Their self-representation as discrete and their search for men who do not bear outward markers of homosexuality are a clear indication not exactly of the eroticisation of the heterosexual man but, more probably, of someone who reveals himself as better at handling the secret and discretion of his relations with other men. My collaborators who seek same-sex partners and present themselves as Machos or Brothers also refer to themselves as "heterossexual" or "bissexual", which increases their value within the universe of online searches. In the view of some their partners, they are not straight or bi but rather pass as hetero, which is equivalent to the ability to disassociate the desire for another man from homosexuality, understood as a dislocation of the male gender or as a deviation from collective values.

Passing for straight is not only a convincing performance of male gender but also involves recognizable signs of participating in the universe of heterosexual sociability. A generation of men who lived through the height of the sexual panic wrought by the AIDS epidemic has tended to see homoerotic desire as a threat to the most esteemed of social values, such as respect for family. Thus, to consider oneself discreet is not only an affirmation of masculinity but of normality, which signifies commitment to a collective order.

In our society, regimes of visibility mark the way men use technologies at least as far back as the invention of the car and the telephone. Cars, for example, enabled men to partake in intimacy with women in public spaces; they used the telephone, historically, to control their partners, for example, to confirm if they were at home on particular days at particular times. The novelty that digital media bring is that they allow a 
segmentation in access to interpersonal networks and the promise of individual modulation of the level of visibility or public exposure of intimacy. In other words, particularly for men with female partners, the use of these media suggest the possibility of remaining within apparent conformity with heterosexist values and conventions, keeping sexual or love relations with persons of the same sex in secret.

This contemporary form of use of digital media seeks to maintain homosexuality within the sphere of the secret, the private and the intimate, awarding public sphere with the privilege of heterosexuality, particularly within the family and at the workplace. Thus, digital media become contemporary instruments that sustain a new type of closet, one which we could perhaps call "the digital closet". In consequence, this usage has also shaped users and their relationships, even to the extent of creating a new form of loneliness. The promise of individual and autonomous control over use of these media generates a new demand for growing ability to manage these segmented spheres of sociability. Ability here signifies a growing demand for rationalization and control over interpersonal relations in order to avoid people's paths from crossing. Failing to respond to this need involves the threat of exposure of secrets and love affairs that - at least in their minds - could lead to separations or fractured friendships, to familial rejection and disastrous impacts on professional life.

In São Paulo, the networks of desire for male same-sex relationships were fueled by the need to avoid prejudice and social rejection during the public health emergency that unfolded over the late 1980s and halfway through the 199os. In this regard, at least for this generation, use of digital media was stimulated more by the desire to establish or sustain a heterosexual image than actually to find someone - something which could occur through media use or without it. Internet use spread by virtue of its ability to keep connectivity "under control", an apparently infinite type of sociability that was always reflexive, edited and managed according to one's own interest.

Yet this control over media use has revealed itself increasingly difficult, due both to limitations of a technological nature as well as users' experience in handling them. Online privacy tends to leak, and dating platforms

11 The closet is an American expression that summarizes the way white middle-class men deal with their homosexuality hidding it or exposing it in a process known as "coming out". For a critical analysis of the racial aspect of the closet script see Manalansan, 2003. 
attempt to respond to this, albeit unsuccessfully, with an ever-increasing amount of privacy control mechanisms. With regard to users, increasingly sophisticated use of platforms and instruments has not protected them from the fear of being "found out"; neither has it led to relations of an exclusively pleasurable nature. Sherry Turkle has enabled us to understand this dialectic of controlled exposure together with continuous complaints and frustrations: the fact that we are dealing with other people in a mediated (and even anonymous) way does not stop us from making a major emotional investment in these relations (2011: 235). In some cases, we may invest even more than in off-line interaction, since online it seems that our connections emerge - right from the start - out of the intimate and the subjective, and through our emotions.

Thus, new digital media are more than just mere instruments. They are subjective and corporeal technologies that then go on to change their users through the very values that mark and encourage the way they are employed. When used by my collaborators in searching for someone "out of the scene", these technologies have had the effect of creating and giving bodily form to men who yearn to live their sexual desire for other men without being associated with homosexuality. It is, as I have indicated above, only an apparent social and subjective paradox. It is in fact a phenomenon which we see in another light when we observe it in its historical context.

A desire to escape the threat of death and social prejudice brought by the AIDS pandemic began to encourage the search for embodied identities that were collectively regarded as healthy and virile. This makes it possible to assert that digital media can be associated with the development of medications and technologies articulated to the then emergent and now consolidated image of the virile gay, fan of bodily practices such as working out at the gym. The entire scenario can be understood as an attempt to keep oneself at a distance from the widely disseminated images of men who were sick and dying from AIDS. This shows how the AIDS epidemic continues to shape people's lives in the way Herbert Daniel and Richard Parker (1991) have described as a "third epidemic", one that followed the actual spread of the virus and the visibility of its biological consequences. In their view, AIDS became a cultural phenomenon that goes far beyond its biological aspect. ${ }^{12}$

12 Parker and Aggleton have developed this cultural perspective about the social consequences of the 
As Paula A. Treichler has stated, "The widespread construction of AIDS as a 'gay disease,' (...) invested both AIDS and homosexuality with meanings neither had alone and produced specific material consequences across a broad social and scientific spectrum." (2004: 6) My research shows how a moral judgment once seen as "scientifically based" remains alive in the representations my interlocutors use to understand their desires. This is particularly the case for the representation that associates same sex desire and risky behavior, which thus requires secrecy and a careful screening of potential partners. This also sheds light on one of the dilemmas emerging from the use of digital media: it is ruled by the imperative of "seeing more than one shows", that is, those who have more clues than the other enjoy a higher degree of safety in their relations. But this also means that one person has greater exposure than the other so that interaction is necessarily unequal and unjust, since having more information is equivalent to having power over another person. The online dispute that has been referred to here, in which the person who reveals himself first or more than the other one rewards the one who exposes himself less with the role of adjudicator, a position that is curiously close to the [male] straight gaze.

The frustration of exposing oneself without reciprocity or, even more, being blocked after showing one's face is equivalent to a probable judgment regarding the person's inability to pass for straight, as well as a fragile "victory" on the part of the one who did not expose himself, whose failure in finding what he was looking for fuses with a certain pleasure in reaffirming his idealized heterosexual position. This regime of visibility, premised on the "discrete man", updates the behavior that Perlongher defined as the terrorist agent of the law (2008: 223), that is the man who engages in sexual relations with another man but in such a way as merely to use or even humiliate him, insofar as the latter is less capable of attaining social recognition as heterosexual.

The use of digital media by men of this generation is characterized by their cultural and historical references, the very ones that shaped their desires, including the desire not to "seem homosexual" in a context in which to be identified as one was equivalent to being declared a social pariah. As Treichler (2004: 37) reminds us, during the worst period of the AIDS epidemic, gay men were seen as sexually driven as alcoholics or drug addicts. Rafael,

epidemic in an inspiring essay entitled HIV and AIDS related stigma and discrimination (2003). 
a thirty year old Grindr user and musician from Rio de Janeiro who has been living in São Paulo for more than seven years states: "I hate the gay scene. (...) I don't want a boyfriend who belongs to it. I can't stand drugs and alcohol. The milieu makes me sick!." Like most of my collaborators, he speaks from the point of view of someone who is "in the know", since he has been to night clubs and other gay spots, although he feels out of place there.

My collaborators are almost unanimous in complaining that digital media do not deliver on their promises. This leads them to substitute or associate the use of different platforms and applications in search of better results. After several years of work following these dynamics as they unfold, I believe that these complaints and user strategies are less indicative of the failure of these medias in making good on what they promise and more indicative of a desire that they function as a panacea for men who have difficulty in negotiating their desire with other people. They are unwilling to negotiate the time and space they reserve to their sexual and love relations with other men within lives that are marked by the priority of work and family - spheres of sociability that are, at least for my collaborators, still heavily marked by heterosexuality, its values and habits.

Rafael is the youngest of the contacts I am working with in my ongoing ethnography. Like my other collaborators, he states he "doesn't have a very active social life", is a homebody and a family guy. He also claims that his disappointments in the use of digital media have led him to reduce his expectations in how he employs them - "as a mechanism to meet people but not to start up relationships. Relationships happen off -line." His observation that these medias may create contacts, yet it is only people who can turn them into relationships is - in its simple and direct wisdom - a welcome provocation.

Translation: Miriam Adelman (UFPR)

Received April 1, 2013 and approved May 5, 2013

\section{Bibliography}

BAYM, Nancy K. 2010. Personal connections in the digital age. Cambridge: Polity Press.

BELELI, Iara. 2012. "Amores online”. In: Larissa Pelúcio et alli (orgs.), Gênero, sexualidade e mídia: olhares plurais para o cotidiano. Marília: Cultura 
Acadêmica Editora. pp. 56-73.

BOELSTORFF, Tom. 2008. Coming of age in second life. Princeton: Princeton University Press.

CASTELLS, Manuel. 1996. The rise of network society. Cambridge: Blackwell. CASTELLS, Manuel. 2011. Sociedade em rede. São Paulo: Paz e Terra.

CRANE, Diana. 2006. A moda e seu papel social. São Paulo: Editora SENAC.

DANIEL, Herbert \& PARKER, Richard. 1991. A terceira epidemia. São Paulo: Iglu Editora.

FOUCAULT, Michel. 2005. História da sexualidade I: a vontade de saber. São Paulo: Graal.

FRANÇA, Isadora Lins. 2010. Consumindo lugares, consumindo nos lugares: homossexualidade, consumo e produção de subjetividades na cidade de São Paulo. Tese de Doutorado em Ciências Sociais, Programa de Pós Graduação em Ciências Sociais, UNICAMP, Campinas.

FRANÇA, Isadora Lins \& SIMÕES, Júlio Assis. 2005. "Do gueto ao mercado”. In: James N. Green \& Ronaldo Trindade (orgs.), Homossexualismo em São Paulo. São Paulo: Editora Unesp. pp. 309-333.

GREGORI, Maria Filomena. 2010. Prazeres perigosos. Erotismo, gênero e limites da sexualidade. Tese de Livre Docência, Departamento de Antropologia, UNICAMP, Campinas.

ILLOUZ, Eva. 2006. "Romance and rationality on the Internet”. Congress of American Sociological Association. Mimeo.

MANALANSAN IV, Martin F. 2003. Global divas: Filipino gay men in the diaspora. London/Durham: Duke University Press.

MASSENO, André. 2011. “O rosto do desejo: posições e (en)cantos”. Anais do XV Encontro Nacional de Linguística e Filologia. Rio de Janeiro: CiFeFil. pp. 2215-2222.

MCQUIRE, Scott. 2008. The media city: media, architecture and urban space. London: Sage.

MISKOLCI, Richard. 2013. "Machos e brothers: uma etnografia sobre o armário em relações homoeróticas masculinas criadas online”. Revista Estudos Feministas, 21 (1): 301-324.

MISKOLCI, Richard. 2009. “O armário ampliado - notas sobre sociabilidade homoerótica na era da internet”. Gênero, 9(2): 171-19o.

MISHEVA, Vessela. 2011. "Online profiles and authenticity”. Curitiba: Congresso da Sociedade Brasileira de Sociologia. Mimeo. 
MOWLABOCUS, Sharif. 2010. Gaydar culture: gay men, technology and embodiment in the digital age. Farnham: Ashgate.

PARKER, Richard \& AGGLETON, Peter. 2003. "HIV and AIDS-related stigma and discrimination: a conceptual framework and implications for action”. Social Science and Medicine, 57: 13-24.

PELÚCIO, Larissa et alli. 2012. "A vida é curta, curta um caso”. São Paulo: RBA. Mimeo.

PELÚCIO, Larissa \& Miskolci, Richard. 2009. "A prevenção do desvio: o dispositivo da AIDS e a repatologização das sexualidades dissidentes". Sexualidad, Salud y Sociedad - Revista Latinoamericana, 1(1): 125-157.

PERLONGHER, Néstor O. 2008 [1987]. O negócio do michê: a prostituição viril em São Paulo. São Paulo: Editora Perseu Abramo.

PRECIADO, Beatriz. 2008. Testo Yonque. Barcelona: Espasa.

PETERSON, Grant Tyler \& ANDERSON, Eric. 2012. "Queering masculine peer culture: softening gender performances on the university dance floor" In: John Laundreay et alli (orgs.), Queer masculinities: a critical reader in education. London/New York: Springer. pp. 119-138.

SEFFNER, Fernando. 2003. Derivas da masculinidade: representação, identidade e diferença no âmbito da masculinidade bissexual. Tese de Doutorado em Educação, Programa de Pós-Graduação em Educação, UFRGS, Porto Alegre.

TREICHLER, Paula A. 2004. How to have theory in an epidemic: cultural chronicles of aids. Durham: Duke University Press.

TURKLE, Sherry. 2011. Alone together: why we expect more from technology and less from each other. New York: Basic Books.

VILLELA, Wilza. 1998. “Homem que é homem também pega aids?” In: Margareth Arilha et alli (orgs.), Homens e masculinidades: outras palavras. Rio de Janeiro: Editora 34/ECOS. pp.129-134.

WEEKS, Jeffrey. 2007. The world we have won: the remaking of erotic and intimate life. New York: Routledge.

WELLMAN, B. 1988. "Networks as personal communities" In: B. Wellman et alli (orgs.), Social structures: a network analysis. Cambridge: Cambridge University Press. pp.130-184.

ZAGO, Luiz Felipe. 2009. Masculinidades disponivel.com: sobre como dizer-se homem gay na Internet. Dissertação de Mestrado em Educação, UFRGS, Porto Alegre. 
ZAGO, Luiz Felipe. 2013. Os meninos: corpo, gênero e sexualidade através de um site de relacionamentos. Tese de Doutorado em Educação, UFRGS, Porto Alegre.

ZAMBONI, Marcio. 2012. Dor, ressentimento e negociação: homossexualidade e soropositividade na trajetória de um herdeiro. Teresina: XV Encontro de C. Sociais do Norte e Nordeste. 